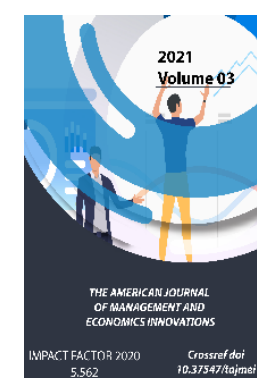

\title{
Educational Significance And Methodology Of Literary Science High School Graduates
}

\author{
Eshmanov Gafur
}

Associate Professor Of The Tashkent Regional Center For Retraining And Advanced Training Of Public Education, Uzbekistan

Journal Website:

https://theamericanjou

rnals.com/index.php/ta

jmei

Copyright: Original

content from this work

may be used under the

terms of the creative

commons attributes

4.0 licence.

\section{ABSTRACT}

The functions of literature are diverse. However, the main task of strong interaction is educational, aesthetic and enlightenment. The educational function of fiction refers to the influence of moral and related qualities on the formation of the spiritual world of the reader, which will find its direct or indirect expression in each work. However, the role of morality in the literature should not be understood as merely a matter of advice. In this regard, it also includes the education of the reader in the spirit of humanity, patriotism, nationalism, justice. The following article looks into the educational role literature.

\section{KEYWORDS}

Literature, Enlightenment, Morality, Spiritual Growth.

\section{INTRODUCTION}

Literature is important to deepen the knowledge of aspirations and to awaken new conscious research. The enlightenment function of fiction is manifested in the realization of these in an integral whole. The main task of literature is to instill in the human heart a love of goodness and a hatred of evil. The writer's weapon is the word, which he skillfully uses to draw scenes in such a way that it is as if the students are participating in the same events, seeing them with their own eyes, with the heroes. Rejoice together and despair together.

This enlightenment function of fiction is the main criterion when working on the analysis of a work of art in literature classes. Students analyze the events of the work, the character of the characters, to identify some of the 
shortcomings, problems, flaws in life and to look for ways to solve them. This case was developed to build the skills and competencies mentioned above. In the case of finding a solution to a case, the student is required to read the work of art, react to the events of the work, describe the characters and analyze the factors that caused the problem, find a solution and justify their opinion.

Goals and objectives of teaching literature and the main purpose of teaching literature in secondary schools:

formation of students' spiritual and moral world, literary and aesthetic taste through the teaching of rare examples of national and world literature, as well as the formation and development of knowledge, skills and abilities in independent thinking, figurative thinking;

to engage students in fiction, to expand and strengthen students' spirituality and worldview through the formation of a world and human nature, national and universal values, as well as a culture of reading in the process of teaching works.

The main task of teaching literature in secondary schools:

To ensure the formation and development of students' oral speech on the basis of the norms of literary language, to increase their speech competence;

High literacy in written speech, adherence to the norms of literary language, the development of skills and abilities to use methodological diversity, and the formation of basic competencies in students based on the content of literary science.

\section{MATERIALS AND METHODS}

Literature is an education tool. It is true that literature does not deal with direct education like a teacher or a parent, but it does cultivate the feeling, the taste, the boundary of imagination between good and evil, the heart and the soul. It is therefore a means of education. Many of today's human tragedies have been and are being studied by scholars around the world, in part because they have moved away from literature or because they have failed to educate their hearts. A heart that has not been nurtured by art, including literature, is prone to savagery, evil, and humiliation. Because it is difficult for evil to enter a heart full of literature, it has to destroy the forts and fortresses that literature has built there before it can turn to evil. The heart, the mind, saturated with literature, is like a solid building. It can withstand many earthquakes. A heart that has not been nurtured by literature and art will not be able to withstand the "lowest tremors." This is a fact that has been proven over the centuries. He knows the role of literature in the development of the human mind, in the spiritual world, in the development of culture, and it may seem superfluous to say this to those who know why the art of the word came into being and what its main function is. But the concern was not in vain, it seems. In the 21st century, one can say "Yes!" It does not seem to be enough. No matter how hard and sad it may be to admit, it is true that literature today is giving up its place fifty years ago on the taste of the masses - on the elements of popular culture mentioned in Hermann Hesse's 1943 novel The Game of Beads. (The main event in the novel takes place in 2200. The historian of the distant future, from his time, from the point of view of the protagonist next, analyzes the cultural life and society of the past - the twentieth century. Scientific, philosophical and psychological analysis of the 
twentieth century. In other words, it was a time when popular culture was flourishing. During this period, people were overwhelmed by the mood of the crowd. The narrator of this work calls this mood "culture of Feltonism". They have lofty goals and spend their lives in fun and entertainment.

Newspapers, mass media, books, works of art are created for this purpose. Scholars of this period did not deal with real science, but with research such as "Friedrich Nietzsche's attitude to women", "Rossini's favorite food", "The peculiarities of being single", or rather, evasion. The public is obsessed with every day and fun culture. Society, on the other hand, manipulates them with the most unnecessary information, which contradicts life and beauty, the essence and mission of man. People of this period read or run until they are free, or watch various shows, pranks, various crossword puzzles, scan words, and other amusement games. Means of subsistence. In these games, there is nothing that enriches a person spiritually, purifies him, and motivates him to the harmony of the world, the unity of mind and body - unity. People engage in such activities in order to distract themselves from economic and political crises, to hide their worries and fears about the future, and to deceive themselves. Hesse concludes from the narrator's language that such a culture and society is doomed to decline.) Therefore, this concern and question did not arise spontaneously. Twenty years ago, Shukur Kholmirzaev also wrote "Will literature die ?!" came up with the question. Although at that time our esteemed writer and those who took part in this debate said, "Literature does not die!" Despite its high-spirited rhetoric, literature has lost even more of its sphere of influence and scope around the world over the past two decades. We see that true works of art, true literature, are the work, the worries, and the sorrows of a narrow circle of people. In today's age of globalization and globalization, literature is no longer seen as an "educational tool." Because today the crowd has found its entertainment and needs in other ways - today it is preoccupied with serials, kidnappings, shows, entertainers and clowns. There is no need for real literature. His taste, level, spirit, imagination, show business, shows, sensations and serials "adorn" and adapt to him. Hesse's prophecies are being confirmed in the 21st century.

\section{REFERENCES}

1. A NEW STAGE OF REFORMING THE TRAINING OF LEGAL PERSONNEL. $F$ Mukhitdinova Review of law sciences 2 (1), 2017.

2. Ideas and teachings on the concept of spiritual and moral education of the younger generation in Uzbekistan FA Mukhitdinova, SS Agzamkhodzhayeva Eurasian Union of Scientists, 2019.

3. Problems of power and management in the works of Eastern thinkers FA Mukhitdinova, HMM Mukhammedov High School, 35-38, 2015.

4. Implementation of human rights protection in Uzbekistan IV Kudryavtsev Eurasian Union of Scientists, 2019.

5. The origins of the idea of civil society FA Mukhitdinova, IN Kudryavtsev ACTUAL ASPECTS OF MODERN SCIENCE, 102-109, 2017. 